\title{
RE-USING OF THE HISTORICAL BUILDINGS IN THE CONTEXT OF SUSTAINABLITY: AN ARCHITECTURAL DESIGN STUDIO STUDY ON OLD GIRLS TEACHER TRAINING SCHOOL
}

\author{
M. Ulusoy ${ }^{\text {a }}$, E. Erdogan ${ }^{\text {b,* }}$, H.A. Erdogan ${ }^{\text {a }}$, M.Oral ${ }^{\mathrm{a}}$ \\ ${ }^{\text {a} S e l c u k ~ U n i v e r s i t y, ~ A r c h i t e c t u r e ~ F a c u l t y, ~ D e p a r t m e n t ~ o f ~ A r c h i t e c t u r e, ~} 42130$ Selcuklu Konya, Turkey - \\ (mulusoy, abdullaherdogan, oralm)@selcuk.edu.tr \\ ${ }^{\mathrm{b}}$ Selcuk University, Fine Arts Faculty, Dep. of Interior Arch. and Env. Design, 42130 Selcuklu Konya, Turkey - \\ interarchebru@hotmail.com
}

KEY WORDS: Adaptive Reuse, Architecture Education, Studio Design Education, Historic Fabric, Sustainability.

\begin{abstract}
:
Refunctioning is a widely used method for protecting historical structures. However, throughout architectural education, functioning historical structures and producing new designs in terms of historical pattern do not attract great attention within the framework of design studios. It is a fact that in such schools that abovementioned items are more popular, the connection between protection oriented studio and design studio is pretty weak. In this study refunctioning was discussed as a design studio topic in relation to the old girls' teacher training school and its immediate surroundings. The primary objective of this design studio is to increase architecture students' awareness in terms of visual and perceptual levels of project designs in historical patterns. Within the context of this manuscript, the experiences gained during design studio process were transferred and discussed.
\end{abstract}

\section{INTRODUCTION}

As societies change, new requirements arise and new buildings are created that suit these requirements. The buildings that lose their original function, preserve their structural characteristics even they lose their function and therefore they are appropriate for re-using. With the spatial program that is shaped according to new needs by using the functionally old buildings via giving them new functions, the existing structure takes form depending on its spatial and structural characteristics. Historical buildings are the expression of a huge accumulation that reflects the cultural, social and economic structure of the past periods (Altınoluk, 1998; Koçan, 2011). These values managed to survive until today. Protecting these values from extinction will cause the re-gaining of the historical buildings for public use by re-newing them to the modern comfort level and making the required functional changes (Altınoluk, 1998; Highfield, 1987).

While historical cities have to meet the changing conditions of the daily life and urban requirements like every creature living in the nature on one hand, they undergo urban development process that necessitate to protect the values composing the city, on the other. The capital city of Seljuk Dynasty, Konya involves many historical structures as it was a capital. From Seljuk Dynasty until today, the mound named Alaaddin Hill has been the focus point of urban distribution in every period. The most important structures of the city centered around this point in the time of Seljuk Dynasty, Ottoman Empire and Republic Period. On the Alaaddin Hill, there are the Alaaddin Mosque and the remains of Seljuk Mansion from the Seljuk Dynasty Period. In the immediate surroundings of the hill, there are Karatay Madrasah, Ince Minaret Madrasah and Hodja Hasan Masjid. Also Serafettin Mosque, İplikci Mosque, Sultan Selim Mosque and Rathaus were constructed on the axle of Alaaddin Hill and Celalettin Rumi (Sufi) Tomb in the Ottoman Empire. It is also observed in the National Architecture Periods that the structuring took place around Alaaddin Hill. These structures are; Post Office Building, Gazi Pasa Primary School, Tekel Building and Girls Teacher Training School. The girls' teacher training school is among these structures; it was selected for having the characteristics of the period and being located in one of the most important areas of the city, and analyzed within the framework of this design studio study (Figure 1).

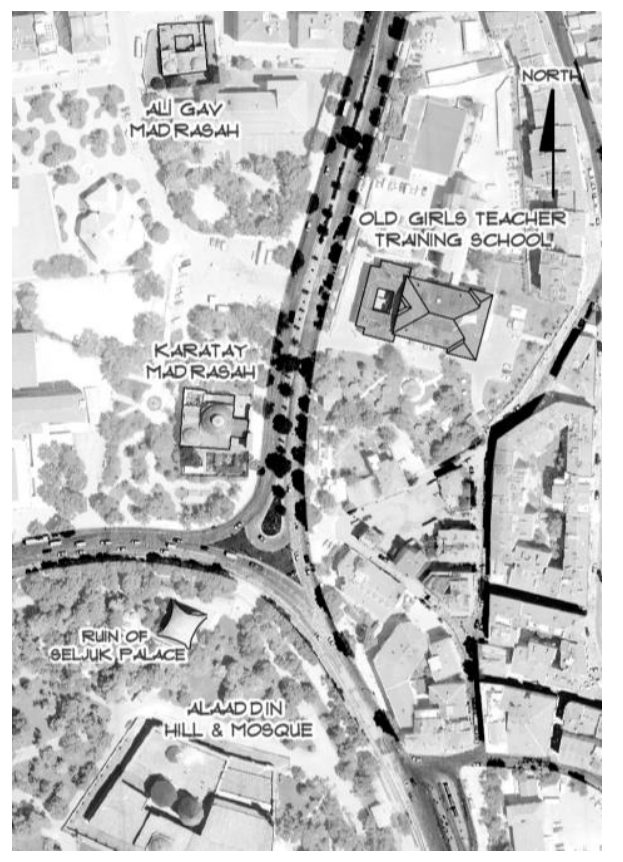

Figure 1. Old Girls Teacher Training School and it's close environment

\footnotetext{
*Ebru Erdogan. Tel.: +90-332-223-2208; Fax: +90-332-2410635. E-mail Address: erdogan@ selcuk.edu.tr.
} 


\section{OLD GIRLS TEACHERS TRAINING SCHOOL}

The thoughts that Ottoman Party of Union and Progress developed in the areas of economy, politics, philosophy, law etc became widespread and influenced the area of architecture as well. The $1^{\text {st }}$ National Architectural Movement, which is called as National Architecture or National Architecture Renaissance Style, emerged in a short time (Aslanoğlu, 1986). This movement reviewed and in a sense tried to validate the architectural and ornament characteristics of past Seljuk and Ottoman structures in an eclectic understanding. The $1^{\text {st }}$ National Architectural Movement, which developed in parallel with all attempts of its period, came to the fore with its interesting fronts and details; rather than new, original plan studies. Because foreign professors in the most important educational institutions of the period prioritized this type of architecture, a generation was raised inclined to study that architecture in this period. What is more, most of the foreign professors became primary implementers of this type of architecture (Sözen \& Dülgerler, 1978).

Muzaffer Bey is one of the most famous architectures of that period; he is known for his versatile works that took place in the last period of Ottoman architecture. He did the most important products of his life in Konya; conducted his studies in one of the famous architects', Vedat Tek's, office (Sözen-Tapan, 1973; Özkan, 1973). Upon the invitation of Husnu Bey, the Governor of Konya, he came to Konya in 1914 to become the chief architect of the county. One of the important projects he did in Konya is, Boys Teacher School, the other is Girls Teacher Training School. Some structures that he started but could not finished due to his health conditions were completed by Architect Falih Ülkü (Sözen \& Dülgerler, 1978).

Konya Girls Teacher Training School started classes in 1915 near Mevlana tomb with a single class (Önder, 1952). The building of the Girls Teacher Training School, which was designed by the Architect Muzaffer Bey in the period of $1^{\text {st }}$ National Architecture and started in 1917, was completed by Falih Ülkü and transferred to the current building (Çipan, 1998). There was a big fire in that building in 1976, the roof and windows of the first floor were burned. Later, it was restored and opened to education again in 1978. It has been used as the Rectorate Building of Seljuk University since 1987(Sözen \& Dülgerler, 1978).

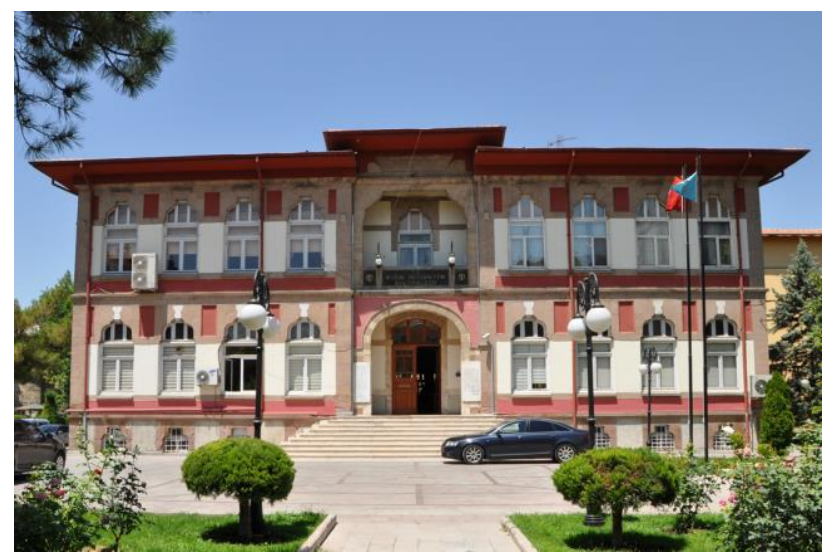

Figure 2. O.G.T.T.S. entrance (east) facade

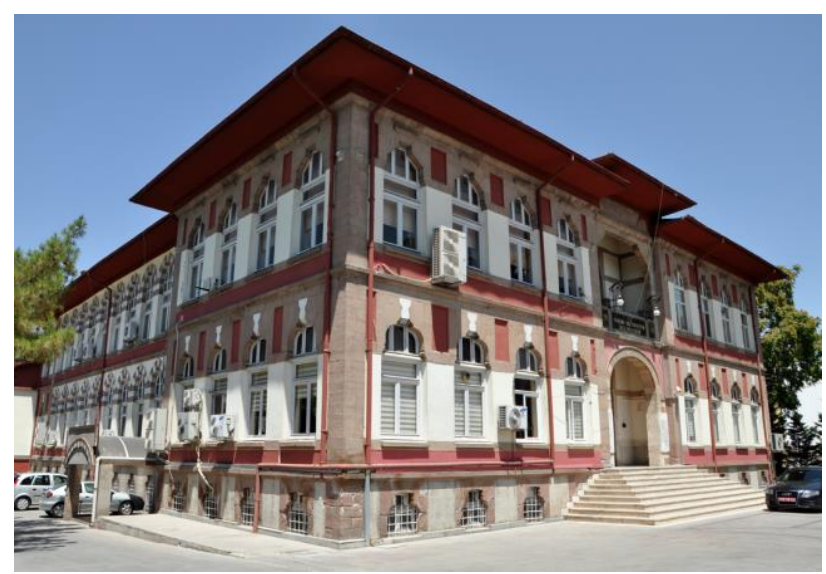

Figure 3. O.G.T.T.S. southeast facade

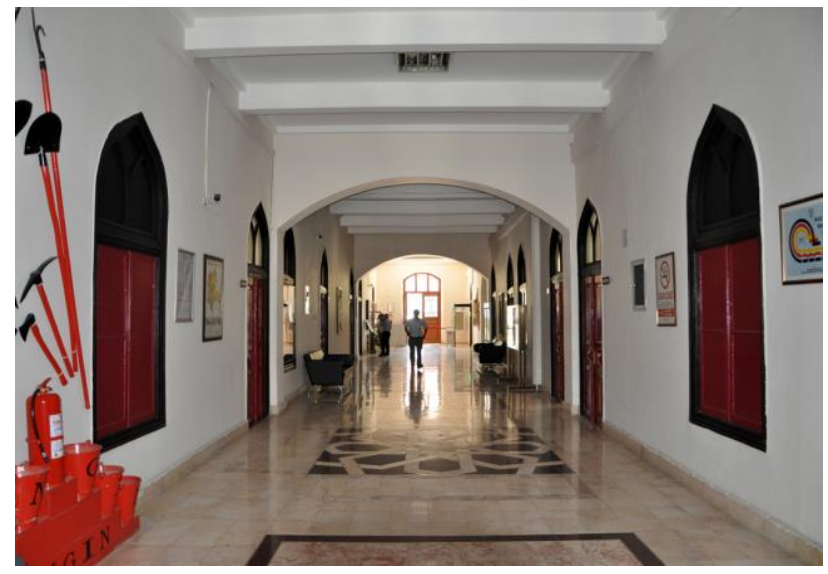

Figure 4. O.G.T.T.S. indoor space view

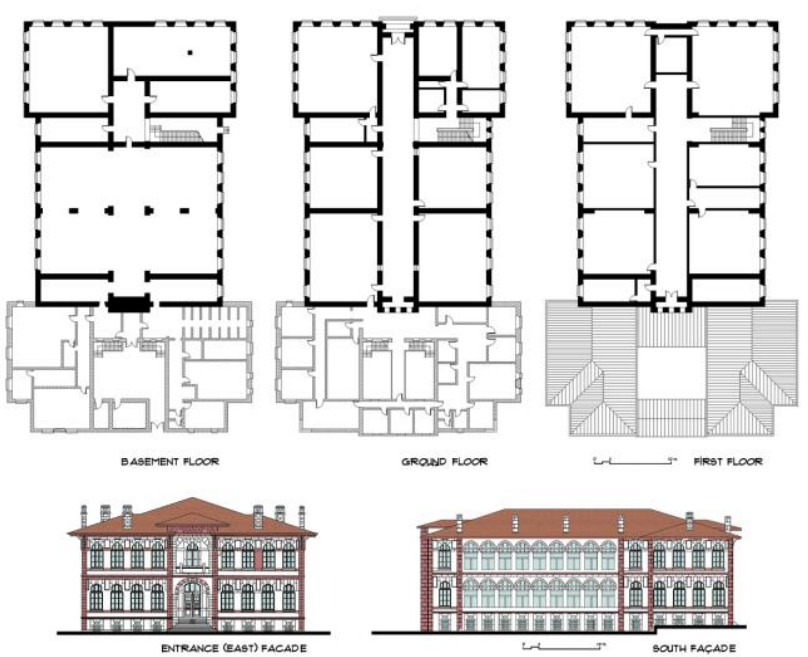

Figure 5. Girls Teacher T.S. plain and facade drawings

The building is in a large garden. It was constructed as a 3 floor building composed of basement, ground floor and first floor. All floors' building plans are the same with a T form, except for the basement. The east front of the building overflows southern and northern directions. The inside of the building was divided into two equal parts by an east-west direction corridor. There are symmetrical spaces in various sizes used for multiple purposes in two sides of the corridor. The main entrance is reached through ten steps; it is situated in the eastern front, 
which was designed widely. In western front, straight ahead of main entrance, there is the second entrance. This entrance stayed in with the additions made to the western front. The building was emphasized by disconnecting floors horizontally with wide belts; and its sticking out eastern part is distinguished from western part with its front formations. There is no exact unity in terms of front formation. Entrances were put to the narrow front, instead of wider fronts. Eastern front was highlighted by a basket arch entrance, made of white and colored stones in alternating order, and the balcony above. The windows of the basement floor were built in small, similar form to each other. The shape of windows of northern and southern fronts is angular horseshoe arch; those windows are different than the ones in eastern front. In the first floor, the upper part of entrance was stayed in and transformed into a balcony. The parts on the entrances in eastern and western fronts were raised from the front and highlighted by surrounding eaves. The building is made of stone, brick, wood, and limestone as the binding material. Rubble stone was used in the basement of masonry construction; in upstairs cutting slime stone was used, and brick was used in party walls. Floors of the building, which were timber in origin, were transformed into ferroconcrete after the modifications took place in 1950s. During the modifications, the length of the floor of the roof eaves were decreased.

This building is across the Karatay Madrasah which was a Seljuk structure, near away from Ali Gav Madrasah and the Ince Minaret Madrasah as a result of its location. Considering the visual, historical, cultural and social dimensions of architecture education, the education taking place in the historical fabric and city center is very important. The reasearch we carried on the re-using of the building revealed that it is appropriate to be used as Faculty of Architecture. Considering visual, historical, cultural, and social dimensions of architecture education, it is thought that being located in the city center will provide various advantages to the faculty building.

Traditional pattern is common in the city center; therefore, the area provides a natural education platform not only to students and professors, but also to guests who will visit the campus. In addition, professional chambers (chamber of architects, chamber of civil engineers etc) located in city center enable local governments (municipalities, governorate etc) to interact with social domains. What is more, it is an elusive opportunity for students and professors in terms of meeting their technical and social needs. With respect to these aspects, it is very important that architecture education is in historical city pattern and city center.

\section{METHOD}

In this study, the old girls' teacher training school, which is one of the examples of 1st National Architecture, was discussed within the context of project 6 course. In this studio study students will first embrace the fact that a building of historical importance has the value of work of art; then they will raise their level of awareness about the product's abstract and symbolic meanings. Detailed analysis of the building will be conducted including its surroundings, and its historical and artistic values will be revealed. Also in the study it was aimed to produce a design process, in which the requirement program that was formed in parallel with newly defined function coincides with the physical and abstract features of the historical building. The participants were composed of 20 students. The main aim of this studio was to be beneficial to the students of architecture, who will design the future city pattern, in terms of producing projects within a historical pattern and structure; advancing in visual and perceptual aspects; and, approaching to the historical pattern.

In the research literature review was conducted about the old girls teacher training school within the context of project 6 course; then, data were collected after observation on site and examination of features of surrounding of the area. The pictures displaying original usage of the building were found from Konya city archives. Then, building's measures and pictures were taken, and building surveys were done. Also, the changes that took place after the building's first construction were determined.

Suggestions were made regarding refunctioning the historical place and its immediate surrounding; the favorable suggestion was to refunction the building as Faculty of Architecture.

The changes made after the first construction of the building were determined. The requirement program of the faculty of architecture which was established within Seljuk University and constitutes of two departments (Architecture and Urban and Regional Planning) was determined. In the last step of the study refunctioning projects were drawn by students in accordance with requirement program of the Faculty of Architecture. However, this historical building is found to be not large enough to response the spatial requirements of the Faculty of Architecture. Thus, out buildings within the existing building land were proposed to be built. For this reason additional buildings were projected to build in the existing land of the building. It was of vital importance to design new buildings in such a way that will not ruin the silhouette of the existing historical building and integrate with it.

\section{STUDIO STUDIES}

The contributions of protection-oriented learning and preserving history in design studio are important and sensitive inputs. On the other hand, this process is different than conventional design process, and requires an important design approach. The design process that will be conducted in this case requires more than a singular protection approach for the new usage of old buildings. In addition to this approach, architecture students are enlightened about the basic obstacles of designing a project that has a pathfinder philosophy in historic preservation applications. Hence, students' awareness about approaching a historical structure will be increased.

In this design studio, in addition to the steps those other design studios follow,

1. Conducting environmental analysis

2. Producing and evaluating alternatives according to the main ideas

3. Fictionalizing scheme according to a concept and producing a developed plan

Documentation and analysis steps are also included. Additional steps are indispensible for historic preservation studies (Langenbach, 1990). This additional step requires drawing the building surveys; and, understanding and studying the connotative meaning of the building (Norberg-Schulz, 1965), other than the physical and historical research. Designer needs to reveal to what extent the building has given sense to people in time; and, define emotions of people that make the building important as a historical place. Therefore, it will be possible to 
determine what important features should be protected and showed in the design that will be formed to reuse; because, people's feelings, emotions, and thoughts, are important in interpretive and philosophic process in order to re-design historical buildings (Langenbach, 1990).

While selecting the design area during the studio-6 study, it was determined that the building of old girls teacher training schools in the city center and the wide area around it are quite suitable for design. These preliminary studies were conducted by negotiating with protection specialists, architectural historians and school administration. During the first five-week period following the determination of the subject and space that the design will take place, students followed the steps: documentation of historical building and its surrounding, historical research, and developing building survey. They had the chance to discuss these steps in studio platforms in weekly periods. However, because in this 14-week studio study the five week period, which was allocated to these steps, would not be enough, previous studies and drawings of the area and building were used. The studies that were prepared after the five-week period were evaluated in the form of presentation plots.

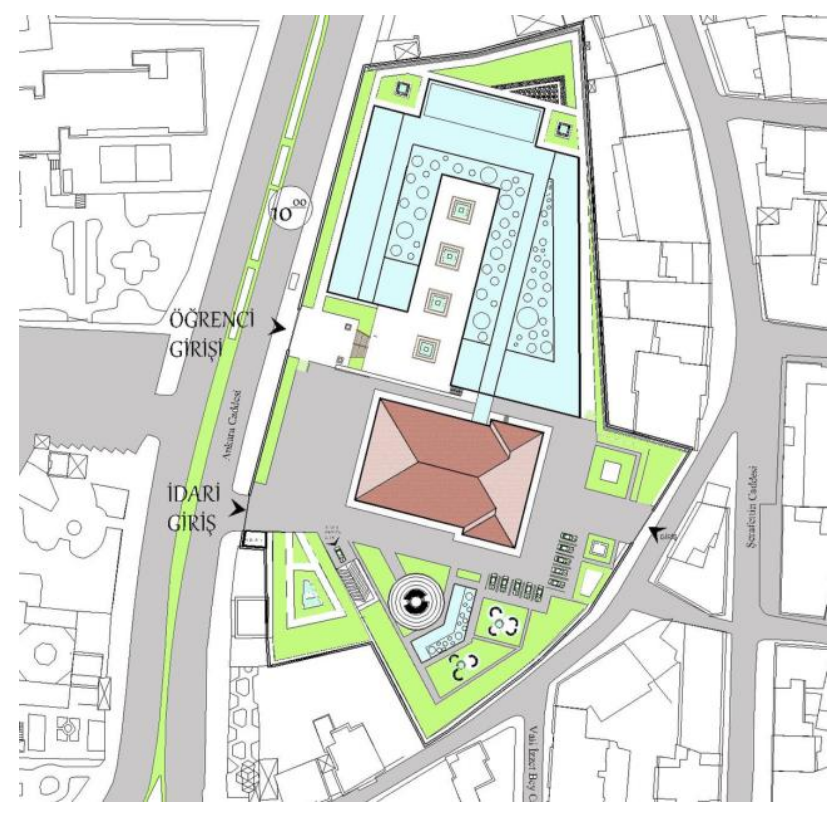

Figure 6. The site plan of a student's project

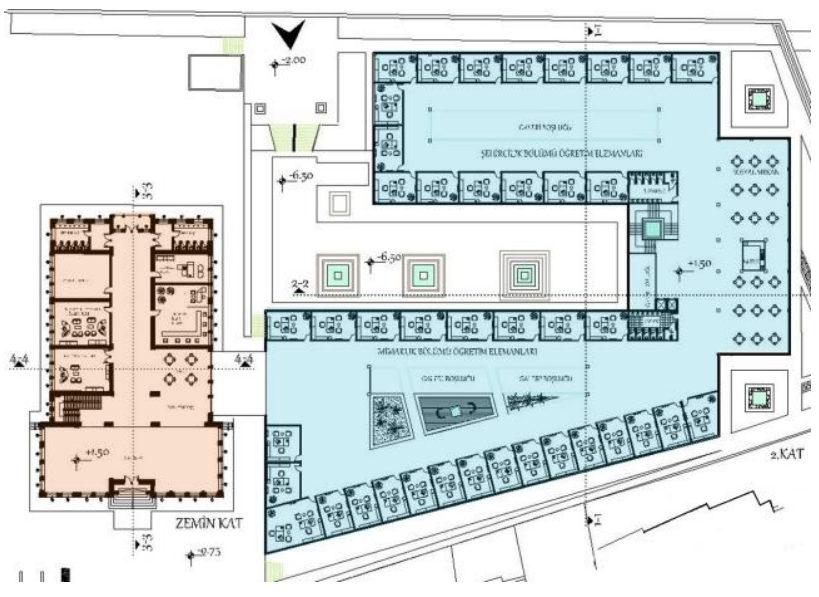

Figure 7. The ground floor plan of a student's project

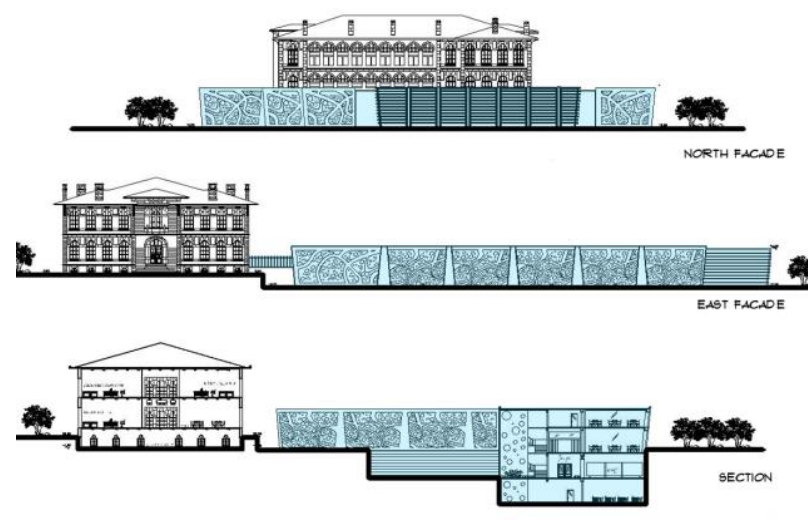

Figure 8. Facades and section of a student's project

In next steps, climatic, topographic environmental analysis was conducted and pedestrian and vehicle approaches were fictionalized. According to the function chart, new functions of old building, and functions of additional buildings were determined; and fictional studies were conducted within the scale of site plan. Students were generally tended to attribute two types of functions to the building of old girls teacher training school. The first group defined a function composed of administrative and management units, cafeteria and a multifunctional hall. Second group defined a function that has administrative units, and academic staff rooms.

The analysis of the old building and new buildings around it were completed until the last step. While building the additional buildings, and especially approaching to the old building students showed a timid attitude. This situation revealed that new buildings spread mainly to the large garden of the old building, and the historical silhouette of the old building should not be blocked due to the slope. This was a real challenge for students. Last but not least, in discussions throughout the semester elaboration of student projects and preparation of final project presentations took place.

\section{CONCLUSION}

One of the most common methods of protection of historic buildings is protection through refunctioning. Especially in recent years the government support regarding protection and restoration of cultural heritage has increased, different support funds have multiplied; therefore, it is now possible to see new example of application every day. No doubt, refunctioning applications occupy a large place among all these application. On the contrary, there are certain deficiencies and mistakes in the formations and regulatory requirements of architects who make protection projects. The majority of architects working in technical offices operating in the field of protection applications do not receive a special training about protecting cultural heritage during their undergraduate education. Related informing sessions at undergraduate level are limited to theoretical briefings. Legal regulations ask very limited number of features from the architects who are active in this field. Required specifications are insufficient to evaluate the 'cultural heritage' proficiency of architect who provides application service. In some universities there is an undergraduate level special studio course about protecting cultural heritage. The problem of this studio class is that documentation of cultural heritage is conducted from the perspectives of problem determination and partial solution suggestions. Studies that 
require design power like refunctioning, or additional buildings to old buildings, are not done or they are insufficient.

The primary purpose of studio 6 study is to integrate design studio and studio of cultural heritage protection. In spite of common renovation and refunctioning studies for old buildings in many cities in Turkey, it is generally very hard to find related studies in architectural studio classes. The purpose of the study is to re-functioning old teacher training school which has a historical background into living spaces especially in a way that serves to a purpose such as Faculty of Architecture and make these buildings live by providing them sustainability in time and interact with environment, by raising the awareness of students in the scope of a design studio study. This study as well aimed to raise the awareness of students within the context of design class, and transform the old girls teacher training school building, which has a historical background, into living spaces, especially into faculty of architecture; and make these historical buildings live and interact with their environment though bringing them continuity. Thanks to this study students were able to embrace the historical features of the building that they work and make sense of it; also, they developed an invaluable perspective by experiencing the design process.

\section{REFERENCES}

\section{References from Journals:}

Aslanoglu, I., 1986. "Evaluation of Architectural Developments in Turkey within the Socio-Economic and Cultural Framework of the 1923-38 Period", M.E.T.U. Journal of Architecture Faculty, 4(1), pp.15-41.

Koçan, N., 2011. "Tarihi Mekânlarda Koruma ve İşlevsel Yenileme: Uşak Paşa Hanı ve Çevresi", Gümüşhane University FBED 1(2), pp.97-108.

Sözen, M., Dülgerler, O.N., 1978. "Mimar Muzafferin Konya Öğretmen Lisesi", M.E.T.U. Journal of Architecture Faculty, 4(1), pp.117-145.

Özkan, S., 1973. "Mimar Vedat Tek (1873-1942)", Mimarlık, Ankara, pp.45-51.

\section{References from Books:}

Altınoluk, Ü., 1998. Binaların Yeniden Kullanımı, YEM Yayınları, İstanbul.

Highfield, D., 1987. Rehabilitation and Re-Use of Old Buildings, E. \& F. N. Spon, London.

Langenbach, R., 1990. "The Teaching of Preservation in the Design Studio: The Relationship Between Theory and Practice", The 78th Annual Meeting of the Association of Collegiate Schools of Architecture Proceedings, Newyork.

Norberg-Schulz, C., 1965. Intentions in Architecture, Cambridge: MIT Press.

Önder, M., 1952. Konya Maarifi Tarihi, Ülkü Basımevi, Konya, pp. 70.

Sözen, M., Tapan, M., 1973. 50 Yılın Türk Mimarisi, İş Bankası Kültür Yayınları, İstanbul, pp.101.

References from Other Literature:

Çipan, I., 1998. Konya Kız Öğretmen Okulu, Unpublished PhD Thesis, Selcuk University, Konya, pp.20-23. 